\title{
5. CROWDFUNDING Z NAGRODAMI
}

(iD) Marcin Bielicki

Uniwersytet Ekonomiczny w Poznaniu

marcin.bielicki@ue.poznan.pl

https://doi.org/10.18559/978-83-8211-083-8/5

\section{Reward-based crowdfunding}

Abstract: Crowdfunding has revolutionized the way projects get done. Reward-based crowdfunding is currently the most important and popular type of crowdfunding. It allows not only to raise capital, but also to engage the community to co-create products. The aim of this chapter is to present the way in which the most important national and international crowdfunding platforms operate. Both the most important elements of a campaign and the factors determining the likelihood of success are presented. Finally, the trends occurring on the market and directions of further development of this form of financing are presented.

Keywords: crowdfunding, entrepreneurship, reward-based crowdfunding.

\subsection{Wstęp}

Crowdfunding jest jedną z najmłodszych form pozyskiwania kapitału (J. Yang, Li, Calic i Shevchenko, 2020), ale już stanowi bardzo atrakcyjną alternatywę dla tradycyjnych źródeł finansowania (Manning i Bejarano, 2016). W dzisiejszej formie powstał on w USA w 2006 roku. Od niespełna dwóch dekad jest jednym z najszybciej rozwijających się obszarów w finansach i rozprzestrzenił się niemalże na całym świecie (Wallmeroth i Wirtz, 2017). Definiowany może być dwojako. Przede wszystkim zwraca się uwagę na jego rolę w dostarczaniu kapitału i wskazuje, że jest to ,gromadzenie często niewielkich kwot od potencjalnie dużej puli zainteresowanych fundatorów" (Short, Ketchen, Mckenny, Allison i Ireland, 2017). Istotne znaczenie ma jednak nie tylko sam kapitał, ale także chociażby informacja zwrotna pomagająca udoskonalić produkt podczas trwającej kampanii (Cornelius i Gokpinar, 2019). To pozwala stwierdzić, że crowdfunding jest specyficzną formą crowdsourcingu opartą przede wszystkim, ale nie jedynie, na wsparciu finansowym.

Obecnie crowdfunding odbywa się przede wszystkim z wykorzystaniem platform internetowych odgrywających rolę pośredników finansowych łączących kapitałobiorców i kapitałodawców (Hagiu i Wright, 2015). Tych pierwszych nazywa 
się najczęściej twórcami (founders), autorami czy kreatorami (creators), drudzy natomiast to najczęściej wspierający - w polskiej nomenklaturze oraz backers, supporters - w anglojęzycznej.

W zależności od typu wspieranych projektów wyróżnia się najczęściej cztery formy crowdfundingu: $\mathrm{z}$ nagrodami ${ }^{1}$ (reward-based crowdfunding), udziałowy (equity-based crowdfuning), charytatywny (donation-based crowdfunding) oraz dłużny (lending-based crowdfunding) (Belleflamme, Lambert i Schwienbacher, 2010; Buysere, Gajda, Kleverlaan i Marom, 2012). Niektórzy autorzy (na przykład Bradford, 2012) zaliczają tutaj także przedsprzedaż. Większość autorów jest jednak zgodnych, że crowdfunding z nagrodami oraz przedsprzedaż są zbyt do siebie podobne, żeby traktować je jako osobne kategorie (Wallmeroth i Wirtz, 2017).

Szczególne znaczenie dla finansowania potencjalnych i obecnych przedsiębiorców mają crowdfunding z nagrodami oraz crowdfunding udziałowy. W pierwszym w zamian za wsparcie otrzymuje się określoną nagrodę (na przykład bilety na koncert, grę planszową czy urządzenie, które było przedmiotem projektu), a w drugim akcje przedsiębiorstwa. Crowdfunding dłużny obejmuje przede wszystkim pożyczki społecznościowe i w porównaniu do dwóch wcześniejszych stanowi marginalne źródło finansowania. Crowdfunding charytatywny natomiast charakteryzuje się całkowicie innymi założeniami. Tutaj wspierający najczęściej nie otrzymują żadnej formy wynagrodzenia, czy to nagrody, czy akcji, w zamian za swoje wsparcie. Realizowane są najczęściej projekty polegające na przykład na gromadzeniu środków na kosztowne leczenie zagraniczne.

Przedmiotem dalszej części rozdziału jest crowdfunding z nagrodami. Przede wszystkim ze względu na fakt, że crowdfunding udziałowy nadal traktowany jest jako „ostatnia deska ratunku” dla przedsiębiorstw, które nie są w stanie finansować się w inny sposób, a nie jako źródło finansowania projektów atrakcyjnych, innowacyjnych (Walthoff-Borm, Schwienbacher i Vanacker, 2018). Celem rozdziału piątego jest ocena crowdfundingu z nagrodami jako sposobu pozyskiwania kapitału. Zawiera się w tym analiza zarówno czynników determinujących sukces kampanii crowdfundingowych, jak i najnowszych trendów w tym obszarze rynku finansowego. Zakres czasowy badania obejmuje lata 2008-2021. W pierwszej kolejności wskazano, jak wygląda proces finansowania za pośrednictwem kampanii w tym typie crowdfundingu. Następnie przedstawiono najważniejsze wyniki badań i związane z nimi charakterystyki kampanii, które mają wpływ na prawdopodobieństwo osiągnięcia zamierzonego celu finansowego, oraz trendy na poziomie światowym oraz polskim, a na tej podstawie analizę SWOT tego rozwiązania.

\footnotetext{
${ }^{1}$ Zauważmy, że w literaturze polskiej crowdfunding tego rodzaju nazywany jest najczęściej crowdfundingiem „,nagrodowym”. Jednak dużo bardziej zrozumiałe (i poprawne w języku polskim) jest mówienie o crowdfundingu ,z nagrodami”.
} 


\subsection{Model działania crowdfundingu z nagrodami}

Crowdfunding z nagrodami jest obecnie najbardziej popularnym typem crowdfundingu i odpowiada za największą część dostarczanego kapitału. Wskazuje się tutaj na dwa powody. Po pierwsze, nadal charakteryzuje się dużo mniej złożonymi regulacjami prawnymi, które utrudniają pozyskiwanie kapitału w crowdfundingu udziałowym (Anglin, Allison, McKenny i Busenitz, 2014). Po drugie, istotne znaczenie ma tutaj fakt, że wspierający w crowdfundingu z nagrodami nie tylko chcą otrzymać produkt, ale też „lubią” samą ideę danego projektu, fakt przynależenia do danej społeczności, a nawet odczuwają „przyjemność” w związku ze wsparciem danego twórcy lub danej kampanii (Schwienbacher i Larralde, 2010). Badania pokazują, że taka dodatkowa niefinansowa motywacja nie występuje w przypadku crowdfundingu udziałowego (Cholakova i Clarysse, 2015).

Wspierający crowdfunding są nazywani też „klientami-inwestorami”, aby podkreślić ich unikalną rolę (Cornelius i Gokpinar, 2019). Podobnie jak klasyczni inwestorzy podejmują decyzje $\mathrm{w}$ warunkach dużej asymetrii informacji. To sprawia, że korzystają z dostępnych danych (Fama, 1991), ale ulegają szeregowi błędów poznawczych podczas przetwarzania tych informacji (Kahneman i Tversky, 1979). Może to prowadzić do irracjonalnych zachowań, jak chociażby zachowań stadnych (herding behavior) (Aren, Aydemir i Şehitoğlu, 2016; Li, Yijing, Liu, Fan, Lim i Liu, 2020).

Dominującym nurtem, w ramach którego naukowcy starają się wyjaśnić, w jaki sposób minimalizować tę asymetrię informacji między innymi w crowdfundingu, jest teoria sygnalizacji (signaling theory) (Spence, 1973). Zgodnie z nią sygnalizujący (w wypadku crowdfundingu twórca kampanii) chce wysłać sygnały do odbiorców (wspierających), które pokażą jakość zarówno jego, jak i projektu. Ma to doprowadzić do redukcji wspomnianej asymetrii informacji, a tym samym ułatwić proces podejmowania decyzji (Connelly i in., 2011). Badania pokazują, że wysyłane sygnały są w stanie zredukować występującą niepewność i skłonić wspierających do finansowania danego projektu (Ahlers, Cumming, Günther i Schweize, 2015; Mollick, 2014).

Obecnie kampanie crowdfundingowe na wszystkich popularnych platformach są tworzone w bardzo zbliżony sposób, tj. tworzą środowisko sprzyjające wysyłaniu wskazanych wyżej sygnałów oraz odbieraniu informacji zwrotnej. Sam proces odbywa się w dwóch fazach (Koch i Siering, 2019). Pierwszy okres to czas trwania kampanii, podczas której zbierane są środki, drugi to praca nad projektem oraz dostarczanie nagród.

\subsubsection{Kampania}

Mimo że w literaturze wskazuje się, iż pierwszym krokiem jest sama kampania, to warto wspomnieć o okresie przed jej rozpoczęciem. Popularne platformy 
(na przykład Kickstarter) umożliwiają z wyprzedzeniem, jeszcze przed startem fundraisingu, zaprezentować szkic projektu. Pozwala to zebrać feedback i już budować zaangażowanie i świadomość wśród społeczności wspierających. Jak pokazują badania, kapitał społeczny jest niezwykle istotnym czynnikiem decydującym o sukcesie, w tym ma ogromne znaczenie dla pierwszych dni kampanii (Cai, Polzin i Stam, 2020).

Następnym etapem jest już sama kampania. Podczas zbiórki twórcy starają się przekonać odbiorców do wsparcia swojego projektu. Występują tu dwa modele (1) wszystko albo nic (all-or-nothing) oraz (2) bierzesz ile bierzesz (keep-it-all) (Cumming, Leboeuf i Schwienbacher, 2020). W pierwszym (dalej AON) twórca otrzyma środki tylko wtedy, gdy zostanie zrealizowany cel danej kampanii. W przypadku nieosiągnięcia wymaganego progu wspierający otrzymują zwrot zaangażowanych środków. Drugi model (dalej KIA) zakłada, że bez względu na zebrane fundusze projekt jest realizowany, to znaczy że nie ma minimalnego progu (celu) do osiągnięcia. Cumming i współautorzy (2020) zauważyli, że przyjęcie formuły AON jest bardzo silnym sygnałem dla wspierających świadczącym o wysokiej jakości i (lub) innowacyjności projektu. Jest to znak dla wspierających, że twórca akceptuje ryzyko związane z tym, iż w przypadku nieosiągnięcia progu nie otrzyma żadnych środków, bo jest pewny powodzenia projektu. To natomiast jest motywacją do wyższego zaangażowania finansowego odbiorców. Finalnie natomiast prowadzi do osiągnięcia statystycznie istotnie lepszych wyników niż w modelu KIA.

Większość kampanii zawiera bardzo zbliżoną strukturę, bez względu na kraj, a nawet platformę. W tabeli 5.1 zawarto najczęściej powtarzające się elementy, które występują w opisie projektów w crowfundingu z nagrodami. Dane te zebrano na podstawie analizy najpopularniejszych platform, tak światowych (Kickstarter, Indiegogo), jak i polskich (Wspieram.to, Zagramw.to).

Tabela 5.1. Elementy kampanii crowdfundingowych

\begin{tabular}{|c|c|}
\hline Element kampanii & Zakres informacji \\
\hline Informacje o twórcy & $\begin{array}{l}\text { - własny opis } \\
\text { - doświadczenie (wsparte i realizowane projekty) } \\
\text { - konta społecznościowe } \\
\text { - zdjęcie }\end{array}$ \\
\hline Elementy audio-wizualne & $\begin{array}{l}\text { - } \text { zdjęcia } \\
\text { - wideo } \\
\text { - } \text { animacje } \\
\text { - ścieżka dźwiękowa }\end{array}$ \\
\hline $\begin{array}{l}\text { Informacje o progresie } \\
\text { kampanii }\end{array}$ & $\begin{array}{l}\text { - liczba wspierających } \\
\text { - stopień osiągniętego celu } \\
\text { - zebrana kwota } \\
\text { - liczba dni do końca }\end{array}$ \\
\hline
\end{tabular}


Tabela $5.1-\mathrm{cd}$.

\begin{tabular}{|c|c|}
\hline Element kampanii & Zakres informacji \\
\hline Opis kampanii & - opis projektu, najczęściej od 1000 do 5000 znaków \\
\hline Odblokowywane cele & $\begin{array}{l}\text { - tzw. stretch goals, w formie: } \\
\text { - celów finansowych - wraz ze wzrostem zebranego kapitału } \\
\text { poprawiana jest nagroda (jakość, dodatki itd.) } \\
\text { - celów społecznościowych - odblokowywane w ramach } \\
\text { działań w mediach społecznościowych, na przykład udo- } \\
\text { stępnienia informacji o projekcie } \\
\text { - celów dziennych - każdego dnia odblokowywana nowa } \\
\text { zawartość projektu - popularne w przypadku na przykład } \\
\text { gier planszowych }\end{array}$ \\
\hline Opis dostępnych nagród & $\begin{array}{l}\text { - zawartość nagrody } \\
\text { - cena } \\
\text { - liczba osób wspierających } \\
\text { - ewentualne limity dostępności (czasowe lub ilościowe) }\end{array}$ \\
\hline Sekcja komentarzy & $\begin{array}{l}\text { - komentarze od wspierających } \\
\text { - komentarze od pozostałych osób } \\
\text { - komentarze od twórców }\end{array}$ \\
\hline Sekcja aktualności & $\begin{array}{l}\text { - aktualności w trakcie trwania kampanii } \\
\text { - aktualności po zakończeniu kampanii }\end{array}$ \\
\hline FAQ & - odpowiedzi na najczęściej pojawiające się pytania \\
\hline Informacja o ryzyku & - opis ryzyka związanego ze wsparciem projektu \\
\hline Recenzje/opinie & $\begin{array}{l}\text { - linki do recenzji zewnętrznych } \\
\text { - wideo z recenzjami } \\
\text { - cytaty z opinii testerów lub pierwszych użytkowników }\end{array}$ \\
\hline Społeczność & $\begin{array}{l}\text { - liczba nowych wspierających } \\
\text { - liczba wracających wspierających } \\
\text { - dane demograficzne wspierających }\end{array}$ \\
\hline
\end{tabular}

Źródło: opracowanie własne na podstawie: www.kickstarter.com, www.indiegogo.com, www.wspieram.to, www. zagramw.to.

\subsubsection{Praca nad projektem}

Po zakończonej kampanii następuje okres pracy nad projektem. W wyjątkowych przypadkach nagrody są dostarczane niemalże natychmiastowo - drogą elektroniczną, na przykład gdy nagrodą są pliki do samodzielnego wydruku 3D albo bilety na koncert. Najczęściej jednak mijają miesiące, a niejednokrotnie nawet lata od zakończenia akcji pozyskania kapitału do dostarczenia nagród². Szczególnie

${ }^{2}$ Idealnie obrazuje to chociażby kampania gry „Kingdom Death: Monster 1.5”, która zakończyła się ogromnym sukcesem w 2017 roku (zebrane ponad $12 \mathrm{mln}$ USD), a nadal nie dostarczono 
w przypadku tak długiego procesu projektowego twórcy podejmują szereg działań mających na celu utrzymanie zaangażowania wspierających. Po pierwsze, w dużych projektach oferuje się tzw. dzieloną dostawę (split shippment), która pozwala wspierającym otrzymywać nagrody sukcesywnie, w miarę ich tworzenia. Jest to popularne działanie chociażby w przypadku gier planszowych, gdzie podstawowa gra jest wysyłana w pierwszej kolejności, a dodatki do niej - w kolejnych falach. Dzięki temu użytkownicy mają okazję wcześniej rozpocząć korzystanie z produktu.

Drugim bardzo popularnym działaniem realizowanym po kampanii jest wykorzystywanie tak zwanego „menedżera wsparcia” (pledge manager). Jest to platfor$\mathrm{ma}^{3}$, która umożliwia wspierającym dokonanie ,późnego wsparcia” (late pledge). W zależności od twórcy takie dodatkowe zakupy są udostępniane wszystkim chętnym albo jedynie tym, którzy udzielili wsparcia podczas kampanii. Szczególnie ten drugi przypadek można traktować jako dodatkowy czynnik motywujący, żeby udzielić wsparcia nawet w wysokości jednego dolara. Pledge manager jest otwierany przeważnie wkrótce po zakończeniu kampanii, a następnie przed wysyłką kolejnych nagród. Trzecim popularnym działaniem realizowanym po kampanii jest angażowanie wspierających w proces współtworzenia produktu. Odbywa się to między innymi poprzez głosowanie nad rozważanymi opcjami, zbieranie opinii czy konkursy na projektowanie konkretnych elementów.

Istotne znaczenie w całym procesie ma bieżąca komunikacja między twórcą a społecznością wspierających. Minimum w większości projektów to cykliczne posty $\mathrm{z}$ aktualnościami, w których twórca informuje o postępie prac nad produktem. Często komunikacja jest bardziej rozbudowana i obejmuje między innymi spotkania online z sesjami pytań i odpowiedzi lub specjalnie w tym celu tworzone grupy na portalach społecznościowych. Wszystko to ma na celu włączenie wspierających w powstawanie produktu oraz utrzymanie ich zaangażowania, gdy oczekują na dostawę nagród.

\subsection{Czynniki sukcesu}

Wyróżnia się cztery główne obszary, które mają wpływ na to, czy kampania osiągnie sukces (Shneor i Vik, 2020) (rysunek 5.1).

wszystkich nagród. W ostatniej aktualizacji z 7 maja 2021 roku podano, że nawet nie wszystkie produkty zostały chociażby zaprojektowane (https://www.kickstarter.com/projects/poots/ kingdom-death-monster-15).

${ }^{3} \mathrm{Na}$ przykład www.gamefound.com jest platformą, która rozpoczynała jako pledge manager, a obecnie oferuje też prowadzenie kampanii crowdfundingowych. 


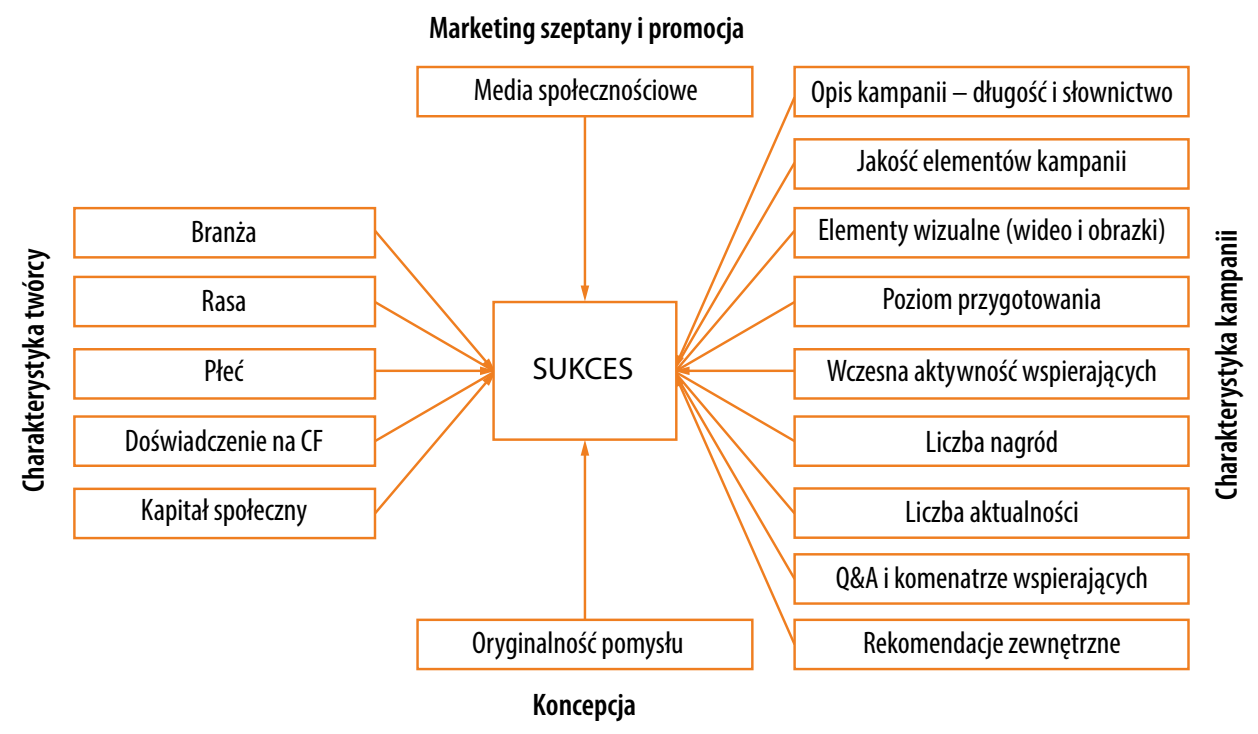

Rysunek 5.1. Czynniki wpływające na sukces kampanii crowdfundingowej Źródło: opracowanie własne na podstawie: (Shneor i Vik, 2020).

Pierwsza grupa czynników dotyczy charakterystyki twórcy. Istotne znaczenie ma branża, w której dany twórca działa i zgłasza projekt. Na przykład odsetek projektów zakończonych sukcesem na Kickstarterze (dane z czerwca 2021) w kategoriach: komiksy, teatr czy taniec, oscyluje w granicach $60 \%$, podczas gdy w takich kategoriach, jak: dziennikarstwo, technologia czy jedzenie - niespełna $25 \%$. Badania pokazują, że także takie dane demograficzne jak płeć i rasa mają wpływ na wynik kampanii (Duan, Hsieh, Wang, R. R. i Wang, Z., 2020; Gorbatai i Nelson, 2015). Bardzo duże znaczenie ma też wcześniejsze doświadczenie twórcy, zarówno we własnych projektach, jak i wsparciu innych (Yang, L. i Hahn, 2015, 2017; Zvilichovsky, Inbar i Barzilay, 2013). Pozwala to na powiększenie kapitału społecznego, który także ma bezpośredni wpływ na wynik kampanii, w szczególności zaś odpowiada za dynamikę fundraisingu w pierwszych jej dniach (Eiteneyer, Bendig i Brettel, 2019; Foster, 2019).

Drugą istotną grupę stanowią czynniki związane z charakterystyką kampanii. Znaczenie ma nie tylko to, co jest zapisane, ale także to, w jaki sposób jest to zrobione. Nawet używanie pozytywnego słownictwa (Anglin, Short $i$ in., 2018) czy pewna doza narcyzmu (Anglin, Wolfe i in., 2018) zwiększają prawdopodobieństwo osiągnięcia sukcesu. Podobnie pozytywnie wpływają takie elementy wizualne jak filmy (Barbi i Bigelli, 2017; Koch i Siering, 2015; Mollick, 2014) czy zdjęcia (Yang J. i in., 2020). Do pozostałych czynników można zaliczyć poziom 
przygotowania kampanii (na przykład spójna tematyka czy wizualizacje), liczbę oferowanych nagród, komunikację ze wspierającymi (na przykład liczba aktualności, komentarze) oraz rekomendacje zewnętrzne (na przykład recenzje, opinie) (Koch i Siering, 2019).

Dwie ważne cechy wpływające na to, czy sama koncepcja pomysłu jest atrakcyjna dla wspierających, to kreatywność i innowacyjność, które można łącznie potraktować jako oryginalność (Koch i Siering, 2019).

Ostatnia grupa jest związana $\mathrm{z}$ marketingiem szeptanym i promocją, w szczególności za pomocą social mediów. $Z$ jednej strony może to pomóc budować społeczność wspierających, z drugiej zaś generuje ryzyko powstawania fake newsów oczerniających daną kampanię czy twórcę (Shneor i Vik, 2020).

\subsection{Trendy na rynku crowdfundingu z nagrodami}

Do analizy trendów w crowdfundingu wykorzystano dane pochodzące $\mathrm{z}$ następujących platform:

- Kickstarter (www.kickstarter.com) oraz Indiegogo (www.indiegogo.com) dwóch największych na świecie platform crowdfundingowych,

- Wspieram.to (www.wspieram.to) oraz Zagramw.to (www.zagramw.to) dwóch największych polskich platform crowfundingowych.

Najważniejsze dane dotyczące poszczególnych platform zestawiono w Tabeli 5.2 .

Tabela 5.2. Porównanie platform crowdfundingowych

\begin{tabular}{|l|c|c|c|c|}
\hline & Kickstarter & Indiegogo & Wspieram.to & Zagramw.to \\
\hline Data utworzenia & 2009 & 2008 & 2013 & 2018 \\
\hline Zebrane środki (USD) & $5,8 \mathrm{mld}$ & $1,6 \mathrm{mld}$ & $26,9 \mathrm{mln}$ & $6,3 \mathrm{mln}$ \\
\hline Łącznie kampanii & 526135 & $800000+$ & 2458 & 21 \\
\hline Liczba kategorii & 15 & 28 & 18 & 1 \\
\hline Model & all-or-nothing & $\begin{array}{c}\text { all-or-nothing } \\
\text { keep-it-all }\end{array}$ & $\begin{array}{c}\text { all-or-nothing } \\
\text { keep-it-all }\end{array}$ & all-or-nothing \\
\hline Koszty & $\begin{array}{c}5 \%+\text { prowizja } \\
\text { za transfer } \\
\text { środków }\end{array}$ & $\begin{array}{c}5 \%+\text { prowizja } \\
\text { za transfer } \\
\text { środków }\end{array}$ & $3,5-9,5 \%$ & N/D \\
\hline Region & świat & świat & Polska & Polska \\
\hline
\end{tabular}

${ }^{*}$ Dane od momentu utworzenia platformy do 7.06.2021.

Źródło: opracowanie własne na podstawie www.kickstarter.com, www.indiegogo.com, www.wspieram.to, www. zagramw.to, www.gamefound.com. 
Skala działalności polskich i międzynarodowych platform jest nieporównywalna. To powoduje, że twórcy najbardziej obiecujących projektów wolą korzystać z platform międzynarodowych (na przykład wszystkie kampanie polskiej firmy Awaken Realms, które biją rekordy na Kickstarterze). Ta ogromna dysproporcja w zasięgu dotarcia do odbiorców powoduje, że firmy (na przykład Go on board właściciel platformy Zagramw.to) decydują się na tzw. kampanie równoległe. Odbywają się one najczęściej w tym samym lub zbliżonym czasie na dwóch platformach: lokalnej i międzynarodowej. Przykładami są kampanie dotyczące wydawanych gier - Wiedźmin: Stary Świat, Łowcy AD 2114 czy Valhalla. Porównanie liczby wspierających i zebranego kapitału dla wybranych kampanii realizowanych na dwóch platformach przedstawiono w tabeli 5.3.

Tabela 5.3. Wyniki kampanii równoległych

\begin{tabular}{|l|r|c|c|c|c|c|}
\hline \multirow{2}{*}{ Kampania } & \multicolumn{3}{|c|}{ Kickstarter } & \multicolumn{3}{c|}{ Zagramw.to } \\
\cline { 2 - 7 } & Wspie- & $\begin{array}{c}\text { Zebrany } \\
\text { kapital }\end{array}$ & $\begin{array}{c}\text { Czas } \\
\text { trwania } \\
\text { kampanii } \\
\text { (dni) }\end{array}$ & $\begin{array}{c}\text { Wspie- } \\
\text { rający }\end{array}$ & $\begin{array}{c}\text { Zebrany } \\
\text { kapital } \\
\text { (PLN) }\end{array}$ & $\begin{array}{c}\text { Czas } \\
\text { trwania } \\
\text { kampanii } \\
\text { (dni) }\end{array}$ \\
\hline $\begin{array}{l}\text { Wiedźmin: } \\
\text { Stary Świat }\end{array}$ & 35694 & 5232423 USD & 17 & 11910 & 3636702 & 17 \\
\hline Tytani & 1843 & 148814 GBP & 23 & 4133 & 386647 & 21 \\
\hline Valhalla & 2897 & 178426 GBP & 31 & 8633 & 527763 & 30 \\
\hline $\begin{array}{l}\text { Lowcy AD } \\
\text { 2114-dodruk }\end{array}$ & 2687 & 277922 USD & 14 & 1440 & 209649 & 21 \\
\hline Łowcy AD 2114 & 1582 & 175516 USD & 30 & 872 & 113532 & 21 \\
\hline
\end{tabular}

${ }^{*}$ Stan na 7.06.2021.

Źródło: opracowanie własne na podstawie www.kickstarter.com i www.zagramw.to.

Fenomenem w crowdfundingu są gry planszowe (por. tabele 5.4 i 5.5). Obserwując statystyki Kickstartera i Wspieram, możemy stwierdzić, że tego typu projekty idealnie wpisują się w ideę crowdfundingu. Na Kickstarterze gry stanowią największą grupę fundowanych projektów. Twórcy gier zebrali zdecydowanie najwięcej funduszy (1,51 mld USD), co stanowi prawie 30\% wartości wszystkich projektów w historii platformy, reprezentując prawie 50\% wszystkich projektów, które osiągnęły wartość powyżej $1 \mathrm{mln}$ USD. Szczególnie wyróżniają się tutaj gry planszowe. Spośród 100 najlepszych kampanii w historii Kickstartera 36 to produkty z tej kategorii.

Także w przypadku polskiej platformy widać, że kategoria Gry bez prądu zdecydowanie dominuje pod względem zebranych środków. W odróżnieniu od Kickstartera platforma nie podaje jednak, jaka część projektów w danej kategorii przyniosła sukces. 
Tabela 5.4. Statystyki projektów z podziałem na kategorie (Kickstarter)

\begin{tabular}{|l|c|c|c|}
\hline \multicolumn{1}{|c|}{ Kategoria } & Liczba projektów & $\begin{array}{c}\text { Zebrane środki } \\
\text { (USD) }\end{array}$ & Odsetek sukcesów \\
\hline Art & 43837 & $142,58 \mathrm{mln}$ & 46,51 \\
\hline Comics & 18919 & $137,71 \mathrm{mln}$ & 61,64 \\
\hline Crafts & 12377 & $18,59 \mathrm{mln}$ & 25,98 \\
\hline Dance & 4335 & $14,11 \mathrm{mln}$ & 61,57 \\
\hline Design & 45546 & $1,22 \mathrm{mld}$ & 39,57 \\
\hline Fashion & 34353 & $184,38 \mathrm{mln}$ & 29,48 \\
\hline Film \& Video & 77601 & $427,23 \mathrm{mln}$ & 37,81 \\
\hline Food & 31621 & $157,47 \mathrm{mln}$ & 25,69 \\
\hline Games & 60877 & $1,51 \mathrm{mld}$ & 43,46 \\
\hline Journalism & 5976 & $16,99 \mathrm{mln}$ & 23,21 \\
\hline Music & 64644 & $241,09 \mathrm{mln}$ & 50,25 \\
\hline Photography & 12894 & $47,49 \mathrm{mln}$ & 33,36 \\
\hline Publishing & 54125 & $196,05 \mathrm{mln}$ & 34,74 \\
\hline Technology & 46575 & $961,06 \mathrm{mln}$ & 21,24 \\
\hline Theater & 12461 & $42,65 \mathrm{mln}$ & 59,92 \\
\hline
\end{tabular}

${ }^{*}$ Stan na 7.06.2021.

Źródło: https://www.kickstarter.com/help/stats?ref=global-footer.

Tabela 5.5. Statystyki projektów z podziałem na kategorie (Wspieram.to)

\begin{tabular}{|l|c|c|}
\hline \multicolumn{1}{|c|}{ Kategoria } & Liczba projektów & $\begin{array}{c}\text { Zebrane środki } \\
\text { (PLN)* }\end{array}$ \\
\hline Muzyka & 457 & 2768188 \\
\hline Książki/Pisma & 334 & 1813164 \\
\hline Komiks & 66 & 585599 \\
\hline Gry komputerowe & 77 & 548250 \\
\hline Gry bez prądu & 271 & 10871164 \\
\hline Inicjatywa & 282 & 4897399 \\
\hline Wydarzenie & 118 & 1185036 \\
\hline Film/fotografia & 111 & 726413 \\
\hline Design & 64 & 717657 \\
\hline Cosplay & 9 & 28883 \\
\hline
\end{tabular}


Tabela $5.5-\mathrm{cd}$.

\begin{tabular}{|l|c|c|}
\hline \multicolumn{1}{|c|}{ Kategoria } & Liczba projektów & $\begin{array}{c}\text { Zebrane środki } \\
\text { (PLN)* }\end{array}$ \\
\hline Edukacja & 79 & 576786 \\
\hline Moda & 41 & 82606 \\
\hline Teatr/Taniec & 56 & 241065 \\
\hline Technologie & 76 & 204437 \\
\hline Wyprawy & 101 & 507528 \\
\hline Sport & 176 & 874225 \\
\hline Start-up & 127 & 261183 \\
\hline Ekologia & 13 & 55014 \\
\hline
\end{tabular}

${ }^{*}$ Stan na 7.06.2021.

Źródło: https://wspieram.to/statystyki_kategorii.

Istotne znaczenie crowdfundingu dla gier planszowych jest widoczne także na poziomie pojedynczych wydawnictw, które decydują się realizować kampanie crowdfundingowe na własnych stronach www, niezależnie od platform zewnętrznych. Można tutaj jako przykład wskazać chociażby polskie wydawnictwa What The Frog czy Czacha Games. Sztandarowym przykładem firmy, która osiągnęła ogromny sukces i stworzyła własną platformę crowdfundingową, jest Awaken Realms. Ten polski wydawca gier planszowych posiada trzy swoje gry na liście top dziesięciu największych projektów z tej kategorii w historii Kickstartera. Najnowszą kampanię zdecydował się prowadzić na stworzonej przez siebie platformie Gamefound. Również ta kampania zakończyła się ogromnym sukcesem. Łącznie prawie 30000 osób przekazało niespełna $5 \mathrm{mln}$ USD na produkcję gry ISS Vanguard. To pokazuje, że przy odpowiedniej skali twórcy są w stanie realizować projekty crowdfundingowe bez dodatkowych pośredników.

\subsection{Analiza SWOT crowdfundingu z nagrodami}

Crowdfunding z narodami jest ciekawą alternatywą pozyskiwania kapitału przez nowoczesne i otwarte technologicznie przedsiębiorstwa z różnych branż. Oprócz jednak zalet i szans rozwoju idei i rynku tej innowacji finansowej musimy pamiętać o jej wadach i zagrożeniach związanych z jej stosowaniem. W sposób syntetyczny przedstawiono je w tabeli 5.6. 
Tabela 5.6. Analiza SWOT crowdfundingu z nagrodami

\begin{tabular}{|c|c|}
\hline Mocne strony & Slabe strony \\
\hline $\begin{array}{l}\text { - łatwy dostęp do kapitału z całego świata } \\
\text { - zachowanie } 100 \text {-procentowej kontroli nad } \\
\text { przedsiębiorstwem } \\
\text { - możliwość szybkiego i taniego przetestowa- } \\
\text { nia pomysłu biznesowego } \\
\text { - szeroki zakres projektów i pod względem } \\
\text { wartości i kategorii }\end{array}$ & $\begin{array}{l}\text { - prowizja dla platformy } \\
\text { - bardzo duża konkurencja }\end{array}$ \\
\hline Szanse & Zagrożenia \\
\hline $\begin{array}{l}\text { - możliwość otrzymania wskazówek od przy- } \\
\text { szłych użytkowników - crowdsourcing } \\
\text { - budowa marki/marketing }\end{array}$ & $\begin{array}{l}\text { - ograniczenia prawne i rosnąca presja poja- } \\
\text { wienia się nowych regulacji } \\
\text { - ujawnienie pracy nad produktem } \\
\text { konkurencji } \\
\text { - presja na ustawianie celu kampanii poniżej } \\
\text { progu rentowności }\end{array}$ \\
\hline
\end{tabular}

Źródło: opracowanie własne.

\section{Mocne strony}

Do najważniejszych mocnych stron finansowania za pomocą crowdfundingu z nagrodami należy przede wszystkim łatwy dostęp do kapitałodawców (klientów) z niemalże całego świata. Szczególnie jeżeli dany twórca decyduje się na zbieranie funduszy za pomocą światowych gigantów, jak Kickstarter czy Indiegogo. Jednocześnie w modelu tym przedsiębiorca prowadzi przedsprzedaż swoich produktów, co zapewnia mu zachowanie 100-procentowej kontroli (udziałów) nad przedsiębiorstwem przy jednoczesnym tanim i szybkim przetestowaniu potencjału pomysłu biznesowego. Umożliwia to zrezygnowanie z kosztownego i nieprecyzyjnego procesu szacowania popytu, produkcji i magazynowania. Twórca tuż po zakończeniu kampanii wie z dokładnością do jednej sztuki, ile nagród musi wytworzyć.

Ostatnią mocną stroną crowdfundingu z nagrodami jest jego elastyczność zarówno w szerokim zakresie wartości kampanii, jak i branż, w których funkcjonują. Występują tu niewielkie projekty o wartości od kilkuset do nawet kilkunastu milionów dolarów. Obejmują one produkty z kilkunastu różnych branż, od gier, poprzez muzykę, hardware aż do mody.

\section{Słabe strony}

Można wskazać dwie zasadnicze słabe strony crowdfundingu z nagrodami. Po pierwsze, wszystkie platformy wymagają opłacenia kilkuprocentowej prowizji za możliwość uruchomienia kampanii. Dlatego też niektóre firmy po zbudowaniu 
własnej bazy klientów rezygnują z dalszych projektów realizowanych w tej formule. Po drugie, największe platformy, które dają dostęp do milionów potencjalnych wspierających, obsługują jednocześnie tysiące projektów. Projekty te konkurują o uwagę i zainteresowanie klientów. Jest to środowisko, w którym rywalizacja, szczególnie dla niedoświadczonych twórców, może być zbyt silna.

\section{Szanse}

Crowdfunding z nagrodami wiąże się też z szansami dla twórców. Przede wszystkim umożliwia wykorzystanie szerokiego grona użytkowników jako potencjalnych pomysłodawców. Dzięki temu sam produkt nagroda może zostać poprawiony jeszcze na etapie projektowania. Ponadto ten sam tłum może stanowić podstawy do budowy marki, szczególnie dla nowo powstających przedsiębiorstw, które nie mają jeszcze ugruntowanej na rynku pozycji.

\section{Zagrożenia}

Autor rozdziału dostrzega trzy zagrożenia rozwoju idei i rynku crowdfundingu z nagrodami. Dotyczą one odpowiednio pojawienia się bardziej rygorystycznych regulacji prawnych i większej kontroli tego rynku, utraty przewagi konkurencyjnej poprzez zaprezentowanie publiczne projektu na jego bardzo wczesnym etapie oraz silnej presji na ustawienie niskiego progu kampanii (w modelu all-or-nothing), który może sprawić, że projekt będzie nierentowny. Zjawisko ta wynika z faktu, że szybko osiągnięty cel kampanii jest potencjalnie silnym sygnałem dla wspierających, że produkty oferowane jako nagrody są wysokiej jakości.

\subsection{Podsumowanie}

Crowdfunding zrewolucjonizował sposób finansowania projektów. Bieżące trendy światowe pozwalają stwierdzić, że na tej zmianie najbardziej skorzystali twórcy produktów kreatywnych, które pozwalają angażować wspierających nie tylko w zakresie pozyskania finansowania, ale także współuczestniczenia $\mathrm{w}$ procesie tworzenia. Trend ten jest widoczny zarówno wśród światowych liderów crowdfundingu, jak i wśród polskich platform. Obecnie nadal platformy międzynarodowe dają w większości przypadków znacznie większą szansę na powodzenie niż ich krajowe odpowiedniki. Twórcy będący światowymi liderami są natomiast w stanie osiągać zbliżone rezultaty nawet bez tych pośredników. Warto zwrócić uwagę, że również po przejściu na własne platformy kontynuują oni finansowanie projektów w formie crowdfundingu. Można na tej postawie wnioskować, że to 
nie tylko popularność Kickstartera czy Indiegogo jest tutaj decydująca, ale sama formuła fundraisingu.

Crowdfunding jest także jednym z najszybciej rozwijających się obszarów badawczych w ostatnich latach. Ciekawym, a dotychczas pominiętym przez badaczy obszarem jest proces przechodzenia z platform zewnętrznych na kampanie realizowane przez twórców we własnym zakresie. Rodzi to szereg interesujących pytań badawczych dotyczących tego, kiedy jest optymalny moment na taką zmianę, czy wszystkie branże mają takie same szanse i wreszcie jak tworzyć społeczność przywiązaną do danego twórcy, a nie platformy. Odpowiedzi na te i kolejne pytania na pewno pojawią się w niedługim czasie, w miarę rozwoju tej innowacji finansowej.

\section{Bibliografia}

Ahlers, G. K. C. C., Cumming, D., Günther, C. i Schweizer, D. (2015). Signaling in equity crowdfunding. Entrepreneurship: Theory and Practice, 39(4), 955-980. https://doi. org/10.1111/etap.12157

Anglin, A. H., Allison, T. H., McKenny, A. F. i Busenitz, L. W. (2014). The role of charismatic rhetoric in crowdfunding: An examination with computer-aided text analysis. W: A. T. H. (Ed.), Research methodology in strategy and management (s. 9, 19-48). Emerald Group Publishing Limited. https://doi.org/10.1108/S1479-838720140000009010

Anglin, A. H., Short, J. C., Drover, W., Stevenson, R. M., McKenny, A. F., Allison, T. H., ... Anglin, A. H. (2018). The power of positivity? The influence of positive psychological capital language on crowdfunding performance. Journal of Business Venturing, 33(4), 470-492. https://doi.org/10.1016/j.jbusvent.2018.03.003

Anglin, A. H., Wolfe, M. T., Short, J. C., McKenny, A. F. i Pidduck, R. J. (2018). Narcissistic rhetoric and crowdfunding performance: A social role theory perspective. Journal of Business Venturing, 33(6), 780-812. https://doi.org/10.1016/j.jbusvent.2018.04.004

Aren, S., Aydemir, S. D. i Şehitoğlu, Y. (2016). Behavioral biases on institutional investors: a literature review. Kybernetes, 45(10), 1668-1684. https://doi.org/10.1108/K-08-2015-0203

Barbi, M. i Bigelli, M. (2017). Crowdfunding practices in and outside the US. Research in International Business and Finance, 42. https://doi.org/10.1016/j.ribaf.2017.05.013

Belleflamme, P., Lambert, T. i Schwienbacher, A. (2010). Crowdfunding: An industrial organization perspective. Pobrane $\mathrm{z}$ https://www.researchgate.net/publication/228468454_Crowdfunding_An_Industrial_Organization_Perspective

Bradford, C. (2012). Crowdfunding and the federal securities laws. Columbia Business Law Review, 1, 1-150.

Buysere, D. K., Gajda, O., Kleverlaan, R. i Marom, D. (2012). A framework for European crowdfunding. European Crowdfunding Network.

Cai, W., Polzin, F. i Stam, E. (2020). Crowdfunding and social capital: A systematic review using a dynamic perspective. Technological Forecasting and Social Change. https:// doi.org/10.1016/j.techfore.2020.120412 
Cholakova, M. i Clarysse, B. (2015). Does the possibility to make equity investments in crowdfunding projects crowd out reward-based investments?. Entrepreneurship Theory and Practice, 39(1), 145-172. https://doi.org/10.1111/etap.12139

Connelly, B. L., Certo, S. T., Ireland, R. D., Reutzel, C. R., Certo, T., Ireland, R. D. i Reutzel, C. (2011). Signaling theory: A review and assessment. Journal of Management, 37(1), 39-67. https://doi.org/10.1177/0149206310388419

Cornelius, P. B. i Gokpinar, B. (2019). The role of customer investor involvement in crowdfunding success. Management Science, 66(1), 452-472. https://doi.org/10.1287/ mnsc. 2018.3211

Cumming, D. J., Leboeuf, G. i Schwienbacher, A. (2020). Crowdfunding models: Keep-it-all vs. all-or-nothing. Financial Management, 49(2), 331-360. https://doi.org/10.1111/ fima. 12262

Duan, Y., Hsieh, T. S., Wang, R. R. i Wang, Z. (2020). Entrepreneurs' facial trustworthiness, gender, and crowdfunding success. Journal of Corporate Finance, 64. https:// doi.org/10.1016/j.jcorpfin.2020.101693

Eiteneyer, N., Bendig, D. i Brettel, M. (2019). Social capital and the digital crowd: Involving backers to promote new product innovativeness. Research Policy, 48, 8. https:// doi.org/10.1016/j.respol.2019.01.017

Fama, E. (1991). Efficient capital markets: II. Journal of Finance, 46(5), 1575-1617.

Feng, C., Li, N., Wong, M. H. F. i Zhang, M. (2019). Initial coin offerings, blockchain technology, and White Paper disclosures. http://dx.doi.org/10.2139/ssrn.3256289

Foster, J. (2019). Thank you for being a friend: The roles of strong and weak social network ties in attracting backers to crowdfunded campaigns. Information Economics and Policy, 49. https://doi.org/10.1016/j.infoecopol.2019.100832

Hagiu, A. i Wright, J. (2015). Multi-sided platforms. International Journal of Industrial Organization, 43(C), 162-174.

Kahneman, D. i Tversky, A. (1979). Prospect theory: An analysis of decision under risk linked references are available on JSTOR for this article: All use subject to http://about. jstor.org/terms. Econometrica, 47(2), 263-292.

Koch, J.-A. i Siering, M. (2015, May). Crowdfunding success factors: The characteristics of successfully funded projects on crowdfunding platforms. 23rd European Conference on Information Systems.

Koch, J.-A. i Siering, M. (2019). The recipe of successful crowdfunding campaigns: An analysis of crowdfunding success factors and their interrelations. Electronic Markets, 29(4), 661-679. https://doi.org/10.1007/s12525-019-00357-8

Li, Y., Liu, F., Fan, W., Lim, E. T. K. i Liu, Y. (2020). Exploring the impact of initial herd on overfunding in equity crowdfunding. Information and Management. https://doi. org/10.1016/j.im.2020.103269

Manning, S. i Bejarano, T. A. (2016). Convincing the crowd: Entrepreneurial storytelling in crowdfunding campaigns. Strategic Organization, 15(2), 194-219. https://doi. org/10.1177/1476127016648500

Mollick, E. (2014). The dynamics of crowdfunding: An exploratory study. Journal of Business Venturing, 29, 1-16. https://doi.org/10.1016/j.jbusvent.2013.06.005 
Schwienbacher, A. i Larralde, B. (2010). Crowdfunding of small entrepreneurial ventures. The Oxford Handbook of Entrepreneurial Finance. https://doi.org/10.2139/ ssrn. 1699183

Shneor, R. i Vik, A. A. (2020). Crowdfunding success: a systematic literature review 2010-2017. Baltic Journal of Management, 15(2), 149-182. https://doi.org/10.1108/ BJM-04-2019-0148

Short, J., Ketchen, D., Mckenny, A., Allison, T. i Ireland, R. (2017). Research on crowdfunding: Reviewing the (very recent) past and celebrating the present. Entrepreneurship Theory and Practice, 41. https://doi.org/10.1111/etap.12270

Spence, M. (1973). Job market signaling. The Quarterly Journal of Economics, 87(3), 355-374. https://doi.org/10.2307/1882010

Wallmeroth, J. i Wirtz, P. (2017). Institutional seed financing, angel financing, and crowdfunding of entrepreneurial ventures: A literature review. SSRN Electronic Journal, 20. https://doi.org/10.2139/ssrn.2967271

Walthoff-Borm, X., Schwienbacher, A. i Vanacker, T. (2018). Equity crowdfunding: First resort or last resort?. Journal of Business Venturing, 33(4), 513-533. https://doi.or$\mathrm{g} / 10.1016 / \mathrm{j}$.jbusvent.2018.04.001

Yang, J., Li, Y., Calic, G. i Shevchenko, A. (2020). How multimedia shape crowdfunding outcomes: The overshadowing effect of images and videos on text in campaign information. Journal of Business Research, 117, 6-18. https://doi.org/10.1016/j.jbusres.2020.05.008

Yang, L. i Hahn, J. (2015). Learning from prior experience: An empirical study of serial entrepreneurs in IT-enabled crowdfunding. International Conference on Information Systems: Exploring the Information Frontier, ICIS. https://doi.org/10.2139/ssrn.3006930

Yang, L. i Hahn, J. (2017). Learning from prior experience: An empirical study of serial entrepreneurs in IT-enabled crowdfunding. Ssrn, 1-21. https://doi.org/10.2139/ ssrn.3006930

Zvilichovsky, D., Inbar, Y. i Barzilay, O. (2013). Playing both sides of the market: Success and reciprocity on crowdfunding platforms. SSRN Electronic Journal, 4. https://doi. org/10.2139/ssrn.2304101 